\title{
LEGAL PROTECTION FOR CHILDREN IN CONFLICT WITH THE LAW: PROCESS AND PROBLEMS
}

\author{
Olif Sekar Prabasini* \\ Juvenile Criminal Law Research Center, Balikpapan, Indonesia \\ *Email: olivsekar@gmail.com
}

\begin{abstract}
The implementation of coaching prisoners, whether male, child or female, in an effort to return prisoners to a good society, is very important, not only material or spiritual, but both must run in balance, these are the main things that support prisoners easily in living their lives. after serving the sentence. Guidance in Correctional Institutions is expected to be able to shape the personality and mentality of prisoners who are considered not good in the eyes of the community to become normal and in accordance with applicable norms and laws Real efforts to guarantee the basic rights of women. The purpose of this study is to determine the rights of a child in obtaining legal assistance, to find out and analyze regulations regarding children, and to analyze the mechanism of legal protection for children who are in conflict with the law.
\end{abstract}

Keywords: Child Protection; Juvenile Criminal Justice System; Children Conflict with the Law

The Indonesian Journal of International Clinical Legal Education DOI: https://doi.org/10.15294/ijicle.v3i3.48264

Submitted: Dec 12, 2020 Revised: May 23, 2021 Accepted: July 29, 2021 Available online at https://journal.unnes.ac.id/sju/index.php/iccle (C) 2021 Authors. This work is licensed under a Creative Commons AttributionShareAlike 4.0 International License (CC BY-SA 4.0). All writings published in this journal are personal views of the authors and do not represent the views of this journal and the author's affiliated institutions.

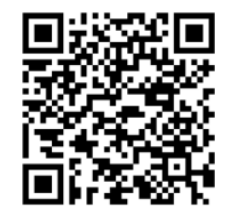




\section{Olif Sekar Prabasini}

\section{INTRODUCTION}

Theoretically, according to Sri Soemantri Martosoewigyo, quoting Stahl's opinion, that the Indonesian state can be said to be a state of law because it has fulfilled the most important elements in a state of law, namely: ${ }^{1}$

1. The government in carrying out its duties and obligations must be based on law or legislation;

2. There is a guarantee of human rights;

3. There is a division of state power;

4. There is supervision from the judiciary

The implementation of coaching prisoners, whether male, child or female, in an effort to return prisoners to a good society, is very important, not only material or spiritual, but both must run in balance, these are the main things that support prisoners easily in living their lives. after serving the sentence. Guidance in Correctional Institutions is expected to be able to shape the personality and mentality of prisoners who are considered not good in the eyes of the community to become normal and in accordance with applicable norms and laws. Real efforts to guarantee the basic basic rights of women.

The United Nations has established a convention on the elimination of all forms of discrimination against women and children (Convention on the Elimination of all forms of Discrimination Against Women or CEDAW) in 1979 and Indonesia ratified it through the Law of the Republic of Indonesia Number 7 of 1984. ratified into Law No. 68 of 1958. All conventions that have been ratified are a shield for women to fight discrimination, exploitation, and human rights violations. ${ }^{2}$

Human rights include an ideal condition and pattern of universal human living standards ${ }^{3}$, where the practice of guaranteeing human rights as a feature of the rule of law in general is known in various literatures, which describes maturity in the state through a life that reflects rights, in particular In Indonesia, it is implemented in various forms, one of which is related to the guarantee of equal status in the eyes of the law for the people which has been guaranteed constitutionally in the 1945 Constitution. One form of implementation of this guarantee is the guarantee of obtaining legal assistance.

1 Sri Soemantri Martosoewigyo, Bunga Rampai Hukum Tata Negara Indonesia, Cetakan Pertama, Alumni, Bandung,1982, pp. 29-30

2 Romany Sihite, Perempuan, Kesetaraan, dan Keadilan: Suatu Tinjauan Berwawasan Gender, PT. RajaGrafindo Persada, Jakarta, 2007, p. 178.

3 Emilda Firdaus, Bentuk Kekerasan pada Perempuan dalam Perspektif Hak Asasi Manusia, Jurnal Konstitusi, Fakultas Hukum Universitas Riau, Vol 1 No. 1, 2008, p. 24. 
Meanwhile, General Recommendation number 25 concerning Article 4 paragraph 1, Convention on the Elimination of All Forms of Discrimination against Women and Children concerning Temporary Special Measures point 7 states that first, the obligation of the State is to ensure that there is no direct and indirect discrimination against women in legislation and that women are protected against discrimination by officials in the public sphere, judiciary, organizations, companies or private individuals, both in the public and private spheres, by a competent judiciary as well as sanctions and other remedial measures. Second, the obligation of the State is to increase the de-facto position of women through concrete and effective policies and programs. Third, the State's obligation is to pay attention to the prevailing gender relations (prevailing gender relations) and sustainable gender-based stereotypes that have an impact on women, not only through individual actions carried out by individuals, but also in laws, regulations and in structures. social institutions. $^{4}$

In accordance with article 1 paragraph (3) of the 1945 Constitution of the Republic of Indonesia after the amendment which stated that Indonesia was a state of law (rechtstaat) not based on mere power (machtstaat). Meanwhile, according to Aristotle, the state of law is a state that stands above the law which guarantees justice for its citizens. According to Aristotle, justice is divided into distributive justice and commutative justice. According to him, good law is law that originates from a sense of community justice and those who govern in the state are fair minds while the ruler is only the holder of law and balance. ${ }^{5}$

The rule of law is a state that stands above the law which guarantees justice for its citizens. Justice is a condition for the creation of a happy life for its citizens. In constitutional history, hereinafter referred to as a narrow legal state as the teachings of Immanuel Kant and Fichte. Where the rule of law is characterized by three things, namely: ${ }^{6}$

1. Recognition and protection of human rights that contain equality in the political, legal, social, economic and cultural fields.

2. An independent and impartial judiciary.

3. Legality in its form

There is a normative and empirical acknowledgment of the principle of the rule of law, namely that all problems are solved by law as the highest guideline. In the perspective of the rule of law (supremacy of law), in essence the highest leader of the state is not actually a human being, but the constitution that reflects the highest law. Normative

4 Convention Watch, Hak Azasi Manusia Instrumen Hukum Untuk Mewujudkan Keadilan Gender, Yayasan Obor Indonesia, Jakarta, 2007, pp. 1035-136.

5 Nomensen Sinamo, Hukum Tata Negara Indonesia, Permata Aksara, Jakarta, 2014, p. 36

6 I Gede Yusa, et. al., Hukum Tata Negara Pasca Perubahan UUD NRI 1945, Setara Press, Malang, 2016, p. 58. 


\section{Olif Sekar Prabasini}

acknowledgment regarding the rule of law is an acknowledgment that is reflected in the formulation of laws and/or constitutions, while empirical acknowledgment is a acknowledgment that is reflected in the behavior of the majority of the people that the law is supreme. In fact, in a republic that adheres to a pure presidential system, the constitution is actually more appropriate to be called the head of state. ${ }^{7}$

As is known, the goals of the state are formally stated in the constitution, so that the constitution is the finalization of various choices that have been decided/agreed upon. It is evident that the relationship between the political system, political behavior, state goals with the legal system and the implementation of the law that supports it is very close. Thus, since the drafting of the 1945 Constitution of the Republic of Indonesia, political activity has appeared, it can be seen that the formal framework of the state/government system is in effect. ${ }^{8}$

The main requirement of a constitution as a human rights constitution is that the process of constitutionalizing human rights must be able to reflect human rights as natural rights, not freeze human rights as positive rights in a closed system (close-ended). The main problem if the suspension occurs is a step backwards for the constitutional protection of human rights. ${ }^{9}$ If the constitution has been officially accepted by a nation and for them the constitution is not only valid in the legal sense (legal), but also a reality in the sense that it is fully necessary and effective. In other words, the constitution is implemented purely and consistently. ${ }^{10}$

The first characteristic of a rule of law is the recognition and protection of human rights. Regarding this characteristic, we can find the guarantee in the preamble and the body of the 1945 Constitution of the Republic of Indonesia, namely in the opening paragraph I that independence is the right of all nations, then in paragraph IV it is also stated that one of the principles, namely "humanitarian fair and civilized", while in the Body of the 1945 Constitution of the Republic of Indonesia we can find several articles such as Article 27 (equal position of every citizen in law and government as well as equal rights to work and a decent living). ${ }^{11}$

7 Jimly Asshiddiqie, Konstitusi dan Konstitusionalisme Indonesia, Sinar Grafika, Jakarta, 2010, p. 127.

8 Masyhur Effendi, Dimensi/dinamika Hak Asasi Manusia dalam Hukum Nasional dan Internasional, Ghalia Indonesia, Bogor, 1993, pp. 41-42.

9 Titon Slamet Kurnia, Konstitusi HAM Undang-Undang Dasar Negara Republik Indonesia Tahun 1945 dan Mahkamah Konstitusi Republik Indonesia, Pustaka Pelajar, Yogyakarta, 2014, pp. 1-2.

10 Kansil dan Christine, Hukum Tata Negara Republik Indonesia Pengertian Hukum Tata Negara dan Perkembangan Pemerintah Indonesia Sejak Proklamasi Kemerdekaan 1945 Hingga Kini, Rineka Cipta, Jakarta, 2008, p. 61.

11 Mahfud MD, Dasar dan Struktur Ketatanegaraan Indonesia, UII Press, Yogyakarta, 1993, pp. 96-97 
Guarantees to obtain legal assistance have been regulated in Law Number 39 concerning Human Rights in Articles 17, 18, 19, and 34. Indonesia has ratified the International Covenant on Civil and Political Rights (Covenant on Civil and Political Rights - International Covenant on Civil and Political Rights), which in Article 16 and Article 26 of the Convention guarantees equality before the law. Everyone has the right to protection from the law and discrimination on the basis of race, color, sex, language, religion, different political views, national or national origin, wealth, birth or other status should be avoided.

The right to legal aid is a human right. A basic catalog that is currently being promoted. Legal aid has developed not only in the context of defending victims of civil and political rights violations, but also as a method of promoting and defending economic rights, social, and cultural. ${ }^{12}$ This is because obtaining legal aid is a form of access to justice for those who are or are dealing with legal issues. Obtaining legal aid is also a manifestation of equality before the law. The principle of equality before the law has been contained in Article 28D paragraph (1) of the 1945 Constitution, namely that everyone has the right to recognition, guarantees, protection and fair legal certainty and equal treatment before the law. This is a consequence of the state of Indonesia being a state of law (article 1 paragraph (3) of the 1945 Constitution as a result of the third amendment). There are three principles of the rule of law (rechstaat), namely the rule of law (supremacy of law), equality before the law, and law enforcement in ways that are not against the law (due process of law). ${ }^{13}$

General provisions for obtaining legal assistance are contained in Law no. 4 of 2004 concerning Judicial Power. Article 37 of Law no. 4 of 2004 states: "Everyone involved in a case has the right to obtain legal assistance." Article 38 of Law no. 4 of 2004 confirms: "In a criminal case, a suspect has the right to contact and ask for help from an advocate." Then, in Article 39 of Law no. 4 of 2004 states: "In providing legal assistance as referred to in Article 37, advocates are obliged to assist in resolving cases by upholding law and justice."

\section{THE RIGHT OF A CHILD WHO MUST GET LEGAL ASSISTANCE}

12 Adnan Buyung Nasution, Bantuan Hukum di Indonesia, Jakarta: LP3ES 2007 pp. xi-xii.

13 Asfinawati dan Mas Achmad Santosa, Bantuan Hukum Akses Masyarakat Marjinal Terhadap Keadilan Tinjauan Sejarah, Konsep, Kebijakan, Penerapan dan Perbandingan Di Berbagai Negara, Jakarta: LBH Jakarta, 2007, pp. 97-98. 


\section{Olif Sekar Prabasini}

Legal aid has been carried out by Western society since Roman times, where at that time legal aid was based on moral values and was more considered a noble job, especially to help people without expecting and/or receiving compensation or honorariums. After the outbreak of the French Revolution, legal aid then began to become part of legal activities or juridical activities by starting to place more emphasis on equal rights for citizens to defend their interests before the courts and until the early 20th century, legal aid was more widely regarded as a job. provide services in the field of law without any compensation. ${ }^{14}$

Legal aid in its broadest sense can be interpreted as an effort to help disadvantaged groups in the legal field. ${ }^{15}$ According to Buyung Nasution, this effort has three interrelated aspects, namely aspects of the formulation of legal rules; aspects of supervision of the mechanism to ensure that the rules are complied with; and aspects of public education so that the rules are lived up.

Maintaining the survival of children is the responsibility of parents, which should not be ignored. Article 45 of Law no. 1 of 1974 Principles of Marriage stipulates that parents are obliged to care for and educate children who are not yet mature or cannot stand alone. Parents are the first to be responsible for the realization of children's welfare both spiritually, physically and socially. Arif Gosita said that children must be protected so that they do not become victims of anyone's actions (individuals or groups, private organizations or governments) either directly or indirectly. ${ }^{16}$

Efforts to protect children need to be carried out as early as possible, from the fetus in the womb until the child is 18 years old. This is based on the conception of child protection that is complete, comprehensive, and comprehensive. The child protection law must also lay down the obligation to provide protection to children based on nondiscriminatory principles, the best interests of the child, the right to life, and survival. And development, as well as respect for children's opinions.

Legal aid to child prisoners is clearly stated in the Child Protection Law Number 23 of 2002 and the Juvenile Justice Law Number 11 of 2012. Article 23 of the SPPPA Law (Juvenile Justice System, hereinafter as SPPA Law) states that "Children have the right to get legal assistance at any time. examination both in the investigation, investigation, prosecution and examination stages in court."

According to the Child Protection Law Number 23 of 2002, it describes the rights of children as part of human rights that must be guaranteed, protected, and fulfilled by parents, families, communities,

14 Bambang Sunggono dan Aries Harianto, Bantuan Hukum dan Hak Asasi Manusia, Bandung, : CV. Mandar Maju, 2009, p. 11.

15 Ibid.

16 Arif Gosita, Masalah Perlindungan Anak, Akademi Presindo, Jakarta, 1989, p. 35 
governments and the state. Wingjosoebroto stated that human rights are rights that should be recognized as rights inherent in humans because of the nature and nature of humans, the absence of these rights will automatically make it impossible for humans to live their dignity as humans. ${ }^{17}$ Children's rights are an integral part of human rights, related to the role of the state, so each country has an obligation to protect, fulfill, and respect children's rights. ${ }^{18}$

Article 26 of the Child Protection Law concerning the Obligations and Responsibilities of the Family and Parents explains that parents are obligated and responsible for nurturing, educating, and protecting their children. Meanwhile, in Article 31 paragraph 2 Chapter VI concerning Fostering Authorities, it is explained that if one of the parents, siblings, or family to the third degree is unable to carry out their functions, then the foster power can be transferred to the authorized institution.

The main human rights that are prohibited by the Criminal Procedure Code are taken from the person of the suspect or defendant, including: ${ }^{19}$

1. Equality of rights and positions and obligations before the law;

2. Must be presumed innocent or presumption of innocence;

3. Arrest or detention is based on sufficient preliminary evidence;

4. The right to prepare a defense early.

The rights of these citizens will be meaningless if the state can arbitrarily (through its apparatus); kill (extrajudicial execution), arrest, detain, torture, search and arbitrarily confiscate the goods of a citizen. These practices deviate from the provisions of a rule of law. ${ }^{20}$ The rights of suspects can be developed, either through laws, court decisions (jurisprudence) or good ways of law enforcement.

According to Mardjono, the principles mentioned above are part of a correct understanding of the due process of law, one of which is that the suspect and the defendant must be given guarantees to fully defend themselves. This principle also explains why legal advisers from the moment of arrest have the right to view case files compiled by investigators as the basis for submitting a case to the prosecutor. ${ }^{21}$

The definition of legal aid in the Criminal Procedure Code according to M. Yahya Harahap states that: "The legal aid referred to in the Criminal Procedure Code includes the provision of professional and formal legal aid services, in the form of providing legal aid services to

17 Meuthia G. Rochman, at. Al., Hak Asasi Manusia Sebagai Parameter Pembangunan, Jakarta, ELSAM, 1997, p. ix.

18 Keputusan Menteri Sosial, Panduan Umum Program Kesejahteraan Sosial Anak, Menteri Sosial, 2010, p 11.

19 Ibid., p. 2.

20 Mien Rukmini, Perlindungan HAM Melalui Asas Praduga Tidak Bersalah dan Asas Persamaan Kedudukan Dalam Hukum Pada Sistem Peradilan Pidana Indonesia, Bandung:Alumni, 2007, p. 111.

21 Ibid. 


\section{Olif Sekar Prabasini}

everyone involved in criminal cases, either free of charge for those who are unable and incapable or providing assistance to those who able by advocates by receiving compensation for services." 22

Law Number 16 of 2011 concerning Legal Aid regulates the new norm in providing legal aid to underprivileged communities. Article 6 paragraph (2) of Law Number 16 of 2011 concerning Legal Aid stipulates that the provision of legal aid to legal aid recipients shall be administered by the Minister of Law and Human Rights and carried out by legal aid providers. Meanwhile, according to Law Number 18 of 2003 concerning Advocates who provide legal assistance are advocates. Article 22 paragraph (1) states that advocates are obliged to provide free legal assistance to justice seekers who are unable. in the hands of a lawyer. Article 8 paragraphs (1) and (2) of Law Number 16 of 2011 concerning Legal Aid stipulates that the implementation of legal aid is carried out by legal aid providers who meet the requirements under the law, namely legal entities, accredited by law, having an office or secretariat that permanent, has a board and has a legal aid program.

With the enactment of Law Number 16 of 2011 concerning Legal Aid, the provision of legal aid is not only in the hands of advocates, but also in legal aid institutions or community organizations that provide legal aid services. Even according to Article 9 letter (a) of Law Number 16 of 2011 legal aid institutions have the right to recruit lawyers, paralegals, lecturers, and students of law faculties.

It is very important the principle of due process of law and equality before the law in realizing the principle of justice for all mentioned above, then legal aid is an absolute right or inherent human right of every individual human being, so that the State as guarantor of the rights of citizens has the most role, both from competence and authority in carrying out the legal aid function. Because of this role, the state requires advocates to provide legal assistance for economically disadvantaged people or groups.

The obligation of advocates in providing legal aid to underprivileged persons or groups free of charge is emphasized in Article 22 paragraph (1) of Law Number 13 of 2003 concerning Advocates, which states that advocates are obliged to provide free legal assistance to justice seekers who unable (do not have access). The constitution guarantees the right of every citizen to receive equal treatment before the law, including the right to access justice through the provision of legal aid.

However, the judiciary is very bureaucratic, expensive, complicated (procedural), isometric in nature (only understood by legal people), causing not everyone to get the same access and treatment when dealing with the law, especially for the poor. People who are rich and

22 M. Yahya Harahap, op.cit, p. 348 
have power, easily access, and get justice, through the hands of the lawyers they hire. This is not the case with poor community groups, they do not have the ability to understand the law and cannot afford to pay lawyers, this causes no equal treatment before the law to access justice. The basic problem that arises is that there is no expansion of equal access for every citizen to get equal treatment before the law, even though the doctrine of justice must be accessible to all citizens without exception (justice for all/accessible to all).

Practices so far have shown that helping people who are unable to access justice are very, very inadequate, if not to say they have been ignored. Legal aid activities carried out by legal aid activists, from campus legal aid institutions, mass organizations, political parties, nongovernmental organizations, are all in suspended animation due to administrative problems and legalization of legal aid practices.

The fact further strengthens the hypothesis given the current practice, the service of advocates is far from the reach of the poor and "vulnerable" groups, commercialization and the elitist attitude of the advocate profession are increasingly providing a fairly wide gap in the hope of realizing the principle of justice for all/accessible to all. This situation is also in line with what is described by Satjipto Rahardjo, that the development of legal aid is approaching a "legal industry", meaning that professionals (advocates) are more involved in running a business than helping those who are in trouble. Legal aid has developed into a large corporation that involves practice in the form of large units and legal services are seen as products that are sold, so that it is like a business. ${ }^{23}$ Oftentimes, cases that find that the attorney is not acting as such will notice that a layperson can perform the same service for a corporate client. ${ }^{24}$ If the action is taken for its own sake or for purposes unrelated to the law, the attorney is not acting as a lawyer. ${ }^{25}$

Legal aid has its own urgency in the category of child prisoners, making it something that must be considered by various related parties, it cannot be only one institution that can provide legal aid rights to child prisoners to the maximum but requires a strong cooperation to carry out the mandate of the legislation. So, the legal aid provider to children must be a top priority by making a separate law that regulates legal aid to prisoners to clarify the procedures and parties who have the authority to grant the legal aid rights.

So, the government should fully support it in the form of regulations that explicitly regulate the provision of legal aid to children

23 'Sajipto Rahardjo, PenegakanHukum Progresif, Penerbit Buku Kompas, Jakarta, 2010, p. 181.

24 `John K. Regan, In re Grand Jury Proceedings in the Matter of Browning Arms CO, Jurnal Westlaw, Volume 1 No. 75, 30 January, 1976.

25 James H. Meredith, Diversified Industries, INC Petitioner, Jurnal Westlaw, Volume 1 No. 77, April, 1977 


\section{Olif Sekar Prabasini}

who are perpetrators of criminal acts and child prisoners. So that children get the right to legal aid as a right they should have for their future development as the nation's successor.

\section{PROTECTION OF CHILDREN IN VARIOUS LEGAL RULES IN INDONESIA}

Mechanisms and various forms of legal protection for children have been regulated in various laws and regulations in Indonesia, starting from the basic constitution of the Republic of Indonesia, the 1945 Constitution to various other laws. The following are various legal rules regarding child protection in Indonesia.

\section{The $\mathbf{1 9 4 5}$ Constitution of the Republic of Indonesia}

Article 28B paragraph (2) states "Every child has the right to survival, growth and development and the right to protection from violence and discrimination."

2. Law of the Republic of Indonesia Number 35 of 2014 concerning Amendments to Law Number 23 of 2002 concerning Child Protection

Article 64

(1) Special protection for children in conflict with the law as referred to in Article 59 includes children in conflict with the law and children who are victims of criminal acts, which are the obligations and responsibilities of the government and society.

(2) Special protection for children in conflict with the law as referred to in paragraph (1) is implemented through:

a. humane treatment of children in accordance with the dignity and rights of the child;

b. provision of special assistant officers for children from an early age;

c. provision of special facilities and infrastructure;

d. imposing appropriate sanctions in the best interests of the child;

e. continuous monitoring and recording of the development of children in conflict with the law;

f. providing guarantees to maintain relationships with parents or family; and

g. protection from identity reporting through mass media and to avoid labeling.

(3) Special protection for children who are victims of criminal acts as referred to in paragraph (1) is implemented through: a. rehabilitation efforts, both within the institution and outside the institution; b. efforts to protect from identity reporting through 
mass media and to avoid labeling; c. providing safety guarantees for victim witnesses and expert witnesses, both physically, mentally, and socially; and d. providing accessibility to obtain information regarding the development of the case.

In addition, some of those regulated in Law Number 23 of 2002 also regulates the child protection commission. In Article 76 the Indonesian Child Protection Commission is tasked with: disseminating all statutory provisions relating to child protection, collecting data and information, receiving public complaints, reviewing, monitoring, evaluating, and supervising the implementation of child protection; provide reports, suggestions, input, and considerations to the President in the context of child protection.

In Law Number 23 of 2002 which is briefly mentioned in article 2. In more detail, these principles are: ${ }^{26}$

1) The principle of non-discrimination.

This means that all rights recognized and contained in the

Convention on the Rights of the Child must be applied to every child without any distinction.

2) The principle of the best for the child (best interest of the child).

Namely that in all actions concerning children carried out by government social welfare institutions or legislative bodies. Therefore, the best interests of the child must be the main consideration (Article 3 paragraph 1).

3) The principle of the rights to life, survival, and development (the rights to life, survival, and development).

Namely that the participating countries recognize that every child has an inherent right to life (Article 6 paragraph 1). It is also stated that the participating countries will guarantee to the maximum extent the survival and development of children (Article 6 paragraph 2).

4) The principle of respect for the views of the child.

It means that children's opinions, especially when it comes to matters that affect their lives, need to be considered in every decision making. This principle is contained in Article 12 paragraph 1 of the Convention on the Rights of the Child, namely: States parties will ensure that children who have their own views will have the right to express their views freely in all matters affecting the child, and these views will be respected. according to the age and maturity level of the child. Affirmation of children's rights in Law no. 23 of 2002 is the legalization of children's rights which

26 `Supriyadi W. Eddyono, Pengantar Konvensi Hak Anak, Jakarta, ELSAM, 2005, pp. 2-4. 


\section{Olif Sekar Prabasini}

are absorbed from national legal norms. Thus, Articles 4 to 19 of Law no. 23 of 2002 created a legal norm (legal norm) about what children's rights are. Children's rights to life, growth and development, protection, and fair participation (Article 4).

3. Law of the Republic of Indonesia Number 11 of 2012 concerning the Juvenile Criminal Justice System

Article 3 Every child in the criminal justice process has the right to:

a. be treated humanely by taking into account the needs according to their age;

b. separated from adults;

c. obtain legal and other assistance effectively;

d. carry out recreational activities;

e. free from torture, punishment or other cruel, inhuman and degrading treatment;

f. not sentenced to death or life imprisonment;

g. not arrested, detained, or imprisoned, except as a last resort and for the shortest time;

h. obtain justice before a juvenile court that is objective, impartial, and in a trial that is closed to the public;

i. identity is not published;

j. obtain assistance from parents/guardians and people who are trusted by the child;

k. obtain social advocacy;

1. acquire a personal life;

m. gain accessibility, especially for children with disabilities;

n. obtain education;

o. obtain health services; and

p. obtain other rights in accordance with the provisions of the legislation.

4. Regulation of the President of the Republic of Indonesia Number 59 of 2015 concerning the Ministry of Women's Empowerment and Child Protection

Article 2 The Ministry of Women's Empowerment and Child Protection has the task of carrying out government affairs in the field of women's empowerment and child protection to assist the President in administering state government.

Article 3, In carrying out the tasks as referred to in Article 2, the Ministry of Women's Empowerment and Child Protection carries out the following functions:

a. formulation and stipulation of policies in the field of gender equality, protection of women's rights, child protection, child development, and community participation.

b. establishment of gender and child data system. 
c. coordination and synchronization of policy implementation in the field of gender equality, protection of women's rights, child protection, child development, and community participation.

d. coordination of the implementation of gender-based protection of women and children.

e. coordinating the implementation of tasks, coaching, and providing administrative support within the Ministry of Women's Empowerment and Child Protection.

f. management of state property/wealth which is the responsibility of the Ministry of Women's Empowerment and Child Protection; and

g. supervision of the implementation of tasks within the Ministry of Women's Empowerment and Child Protection.

Article 15

The Deputy for Child Protection has the task of carrying out policy formulation as well as coordinating and synchronizing the implementation of policies in the field of child protection.

Article 16 In carrying out the duties as referred to in Article 15, the Deputy for Child Protection carries out the following functions:

a. formulation of policies in the field of child protection;

b. coordination and synchronization of policy implementation in the field of child protection;

c. preparation of norms, standards, procedures, and criteria in the field of child protection;

d. compilation of gender data in the field of child protection;

e. providing technical guidance and supervision in the field of child protection;

f. monitoring, analysis, evaluation, and reporting on the implementation of policies in the field of child protection;

g. implementation of the administration of the Deputy for Child Protection;

h. implementation of other functions assigned by the Minister.

5. Regulation of the Minister of Women's Empowerment and Child Protection of the Republic of Indonesia Number 18 of 2019 concerning the Implementation of the Children's Forum

Article 2 paragraph (2)

The Minister of Women's Empowerment and Child Protection Regulation concerning the Implementation of Children's Forums is used as a reference for the central government, provincial governments, district/city governments, sub-districts, and village/ kelurahan governments in organizing the Children's Forum. (2) In addition to being a reference for the central government, provincial governments, district/city governments, sub-districts, and village/ kelurahan governments, this Ministerial Regulation can also be used 


\section{Olif Sekar Prabasini}

as a reference for community organizations or other institutions dealing with child protection.

Article 5

(1) The coaches as referred to in Article 4 letter a are divided in stages according to the area where the Children's Forum is located.

(2) The supervisor has the task of fostering and supervising the implementation of the fulfillment of the Rights of the Child and the Special Protection of the Child in the implementation of the Children's Forum.

Based on article 28D paragraph (1) of the Constitution, it states "everyone has the right to recognition, guarantees, protection and fair legal certainty and equal treatment before the law". Legal aid or what is known as legal aid is a service to provide legal advice to people who are unable to obtain legal representation and access to courts, both non-litigation and litigation fairly, therefore, for any legal action that is alleged to the accused, it is necessary to also pay attention to the rights of the accused. their right to receive truth and justice in accordance with the legal actions they take without any discrimination. $^{27}$

\section{LEGAL PROTECTION MECHANISMS FOR CHILDREN IN CONFLICT WITH THE LAW}

The Criminal Procedure Code (KUHAP) has appointed and placed the suspect or defendant in a position of dignity, as a creature of God who has complete human dignity. The suspect or defendant has been placed in the Criminal Procedure Code in the position of his entity and dignity as a human being, which must be treated in accordance with noble human values. The law must be enforced, but in the implementation of law enforcement against a suspect or defendant, the main human rights inherent in him must not be stripped. ${ }^{28}$

An inmate who is serving a sentence in a correctional institution because he has committed a criminal act has an obligation that must be

27 Frans Hendra Winata, Pro Bono Public, Hak Konstitusional Fakir Miskin Untuk Memperoleh Bantuan Hukum, Gramedia, Jakarta, 2009, p. 76.

28 M. Yahya Harahap, Pembahasan Permasalahan dan Penerapan KUHAP Penyidikan dan Penuntutan, Jakarta: Sinar Grafika, 2009, pp. 1-2. 
carried out, the obligations of this prisoner are listed in Article 23 of the Academic Paper of the Draft Law on Corrections, namely: ${ }^{29}$

a. Participate in a coaching program that includes physical and spiritual care activities, as well as certain other activities in an orderly manner.

b. Follow religious guidance and education in accordance with their religion and beliefs.

c. Participate in work training activities carried out for 7 (seven) hours a day.

d. Comply with prison rules and regulations while participating in the program of activities.

e. Maintain courtesy, be respectful and be honest in all their behavior, both towards fellow residents and more specifically to all officers.

f. Maintain security and order in the interaction of fellow residents.

g. Reporting to the officer all problems that arise in the implementation of the construction of prisoners, more specifically to problems that can trigger the occurrence of disturbances in security and order.

h. Avoid all forms of hostility, conflict, fights, theft, and the formation of solidarity groups among inmates in prisons.

i. Maintain and maintain all inventory items received and all facilities and infrastructure in the implementation of prisoner development.

j. Maintain the cleanliness of the body and the environment in prison.

Legal aid is a medium that can be used by everyone in order to claim their rights for treatment that is not in accordance with applicable legal rules. This is based on the importance of legal protection for every human being as a legal subject in order to ensure law enforcement. This legal aid is to defend the community regardless of background, ethnicity, origin, descent, skin color, ideology, political beliefs, rich and poor, religion and the group of people being defended. ${ }^{30}$

However, in reality there are still many people who are unable to pay for the services of legal advisors in accompanying their cases. Even though he has facts and evidence that can be used to lighten or show the truth in the case, so that their case does not reach the court. Whereas legal aid is the right of every poor person that can be obtained without paying (public probono). And for those who are less able, can apply for legal aid free of charge (free) for the provision of legal aid. ${ }^{31}$

The guarantee for everyone to get equal treatment before the law as a reflection of the principle of quality protection of the law and the principle of equal justice under the law which is guaranteed in the 1945

29 B Mardjono Reksodiputro, Naskah Akademik Rancangan Undang-Undang Tentang Lembaga Pemasyarakatan. Jakarta. Badan Pembinaan Hukum Nasional Departemen Hukum dan HAM RI, 2009, p. 90.

30 Sudikno Mertokusumo, Hukum Acara Perdata Edisi Ke Lima, Liberty, Yogyakarta, 1998. p. 16.

31 Ibid. 


\section{Olif Sekar Prabasini}

Constitution article 28d paragraph (1) which reads "everyone has the right to recognition, guarantee, protection and certainty, fair law and equal treatment before the law".

The definition of legal aid can also be seen in law number 16 of 2011 concerning legal aid, as contained in article 1 paragraph (1) which reads "legal aid is legal services provided by legal aid providers free of charge to recipients of legal assistane", then Article 1 paragraph (2) states that 'recipients of legal aid are poor people or groups of people. As well as in article 1 paragraph (3) it is stated that "legal aid providers are legal aid institutions or community organizations that provide legal aid services based on this law."

Legal aid to child prisoners is clearly stated in the child protection law number 23 of 2002 and the juvenile justice law number 11 of 2012. Article 23 of the SPPPA Law (Child Criminal Justice System) paragraph (1), in every examination, the child must be given legal assistance and accompanied by a legal aid supervisor and accompanied by a community counselor or other assistant in accordance with the provisions of the legislation. a person trusted by the victim's child and/or child witness, or social worker.

\section{CONCLUSION}

Legal aid can be interpreted as all forms of assistance or the provision of services in relation to legal issues provided by someone who has legal expertise to those involved in cases, either directly or indirectly, by prioritizing those who cannot afford it, as for legal aid according to Article 1 point (9) Law No. 18 of 2003 concerning Advocates is a legal service provided by advocates free of charge to clients who can't afford it. The provision of legal aid is a supporting tool for law enforcement in general and efforts to protect human rights from arbitrary actions by law enforcement officers, then there is no benefit in realizing the objectives of the criminal justice system. In general, the definition of a legal aid institution is an institution that is non-profit in nature. It was specifically established to provide the best possible service free of charge to those who need legal assistance but cannot afford it, or are legally blind, or are oppressed by the cases they are facing. However, there are also legal aid institutions that seek profit. Therefore, you should ask for definite clarity when first consulting. In addition, the right to obtain legal assistance for those who are underprivileged, legally blind, or for other reasons is also stated in SEMA (Supreme Court Circular Letter) of 2010 No. 10 Article 27 which reads, A person who is entitled to receive services from a legal aid post are people who are unable to pay for the services of an advocate, especially women and children and persons with disabilities, according to the prevailing laws and regulations. 


\section{REFERENCES}

Asfinawati, A., et.al. (2007). Bantuan Hukum, Akses Masyarakat Marjinal Terhadap Keadilan. Jakarta: LBH Jakarta.

Asshidiqie, J. (2005). Kekuasaan Kehakiman di Indonesia (Aspek-aspek Perkembangan). Jakarta: UII Press

Broto, S. T. (1983). Dasar-dasar Hukum Acara Pidana. Bandung: Amicom Bandung.

Eddyono, S. W. (2005). Pengantar Konvensi Hak Anak. Jakarta: ELSAM.

Eddyono, S. W. (2006). Etika Dan Tanggung Jawab Profesi Hukum di Indonesia. Jakarta: Sinar Grafika.

Fajar, N. D. M. (2010). Dualisme Penelitian Hukum Normatif \& Empiris. Yogyakarta: Pustaka Pelajar.

Ibrahim, J. (2007). Teori dan Metodologi Penelitian Hukum Normatif. Malang: Banyumedia Publishing.

Kamil, A., \& Fauzan, F. (2010). Hukum Perlindungan dan Pengangkatan Anak di Indonesia. Jakarta: Rajawali Pers.

Keputusan Menteri Sosial. (2010). Panduan Umum Program Kesejahteraan Sosial Anak.

Lamintang, P. A. F. (1990). Dasar-Dasar Hukum Pidana Indonesia. Bandung: Sinar Baru.

Moeljatno, M. (2002). Asas-Asas Hukum Pidana. Jakarta: PT Rineka Cipta.

Mudzakkir, M. (2001). Posisi Hukum Korban Kejahatan dalam Sistem Peradilan Pidana. Jakarta: Program Pascasarjana FH-UI.

Muladi, M., et.al. (1984). Pidana dan Pemidanaan, Semarang: Badan Penyediaan Bahan Kuliah Fakultas Hukum Universitas Diponegoro Semarang.

Packer, H. L. (1968). The Limit of Criminal Sanction. California: Standford University Press.

Patra, M. Z. A., et. al. (2009). Panduan Bantuan Hukum Indonesia. Jakarta: YLBHI dan PSHK.

Purnomo, B. (1985). Asas-Asas Hukum Pidana. Jakarta: Ghalia Indonesia.

Rahardjo, S. (2008). Lapisan-Lapisan dalam Studi Hukum. Malang: Bayu Media.

Rochman, M. G., et.al. (1997). Hak Asasi Manusia Sebagai Parameter Pembangunan. Jakarta: ELSAM. 


\section{Olif Sekar Prabasini}

Salman, O. (1987). Sosiologi Hukum, Suatu Pengantar. Bandung: Armico.

Soekanto, S. (1983). Bantuan Hukum Suatu Tinjauan Sosio-Yuridis. Jakarta: Ghalia Indonesia.

Soemitro, R. H. (1990). Metodologi Penelitian Hukum. Jakarta: Ghalia Indonesia.

Sudarto, S. (1990). Hukum Pidana I. Semarang: Yayasan Sudarto, Fakultas Hukum UNDIP.

Sudaryono, S., et.al. (2005). Buku Pegangan Kuliah Hukum Pidana, Surakarta: Fakultas Hukum Universitas Muhammadiyah Surakarta.

Sunggono, B., et.al. (2009). Bantuan Hukum dan Hak Asasi Manusia. Bandung: Mandar Maju.

Suparni, N. (1991). Tindak Pidana Subversi Suatu Tinjauan Yuridis. Jakarta: Sinar Grafika.

\section{Conflicting Interest Statement}

All authors declared that there is no potential conflict of interest on publishing this article.

\section{Funding}

None

\section{Publishing Ethical and Originality Statement}

All authors declared that this work is original and has never been published in any form and in any media, nor is it under consideration for publication in any journal, and all sources cited in this work refer to the basic standards of scientific citation.

Cite this article as:

Prabasini, O. S. (2021). Legal Protection for Children in Conflict with the Law: Process and Problems. The Indonesian Journal of International Clinical Legal Education, 3(3), 381-398. https://doi.org/10.15294/ijicle.v3i3.48264 